\title{
Late Cenozoic catfishes of Southeastern Europe with inference to their taxonomy and palaeogeography
}

\author{
Oleksandr Kovalchuk and Carl J. Ferraris
}

\begin{abstract}
We describe fossil catfish (Siluriformes) material from late Miocene through Pleistocene strata of Southeastern Europe. The material under study is represented by disarticulated bones from 26 localities in the territory of Southern Ukraine and the Russian Federation. Catfish fossils in that region are represented by members of two genera, Heterobranchus and Silurus, of two families (Clariidae and Siluridae, respectively), and five species, including one as new for science (Silurus spinosus n. sp.) and two described in open nomenclature (Silurus cf. S. glanis, Silurus sp.). The presence of †Heterobranchus austriacus in the late Sarmatian of Southern Ukraine can be explained by expansion of this species from Africa to Europe during the late Miocene (earlier remains of this taxon were documented only in Central and Western Europe). Geographic distribution of Silurus soldatovi was broader in the past as indicated by the numerous findings of its bones in the late Miocene and Pliocene deposits of Southeastern Europe. Modern Silurus glanis first appeared during the final stage of late Miocene (Pontian) and probably supplanted $S$. soldatovi because of its wider ecological plasticity (especially temperature tolerance - this species can spawn in cooler waters). An interesting evolutionary trend has been observed in the change of size, shape and orientation of denticulations on the shaft of pectoral-fin spine in different species of the genus Silurus. Such tendency may be explained in terms of the oligomerization of homologous structures, but this question deserves a special study and is not addressed herein.
\end{abstract}

Kovalchuk, Oleksandr. Department of Paleontology, National Museum of Natural History, National Academy of Sciences of Ukraine, 15 Bogdan Khmelnitsky str., Kyiv 01601 Ukraine. biologiest@ukr.net Ferraris, Carl J. National Museum of Natural History, Smithsonian Institution, Washington; 545 NE Floral Place, Portland, Oregon 97232 U.S.A. carlferraris@comcast.net

Keywords: Clariidae; Siluridae; new species; late Miocene; Pliocene; Pleistocene

Submission: 2 December 2015 Acceptance: 15 August 2016

http://zoobank.org/E05568FD-126B-4E62-BD29-0FAD09298660

Kovalchuk, Oleksandr and Ferraris, Carl J. 2016. Late Cenozoic catfishes of Southeastern Europe with inference to their taxonomy and palaeogeography. Palaeontologia Electronica 19.3.34A: 1-17

palaeo-electronica.org/content/2016/1594-cenozoic-catfishes-of-europe

Copyright: Palaeontological Association September 2016 


\section{INTRODUCTION}

Catfishes (Order Siluriformes) along with cyprinids, pikes and percids form the core of the late Neogene freshwater fish fauna of Southeastern Europe. The oldest skeletal catfish remains in Europe are from the middle Eocene (?) of Germany (Böhme and Ilg, 2003) identified therein as Astephus resimus Lundberg, 1975 (family Ictaluridae), a species originally described from western North America. Earlier remains, in the form of otoliths, were reported from the Late Cretaceous of Germany (Schwarzhans, 2010) and the middle Paleocene of Denmark (Schwarzhans, 2003), as Arius danicus Koken, 1891. Isolated unidentified skeletal remains of catfishes are abundant throughout late Miocene and Pliocene deposits of Europe. Air-breathing catfishes (Clariidae) are known in the fossil record of Austria (Thenius, 1952; Böhme, 2002), Germany (Weiler, 1928), Slovakia (Böhme and Ilg, 2003), Turkey (Gillet et al., 1978) and represented by the genus Heterobranchus Geoffroy-Saint-Hilaire, 1809. Bones assigned to the genus Silurus Linnaeus, 1758 of the family Siluridae were found from late Miocene, Pliocene and Pleistocene strata in Austria (Gaudant, 1994; Böhme, 2002), Bulgaria (Kamenov and Kojumdshieva, 1983), Germany, Greece, Hungary, Slovakia (Böhme and Ilg, 2003), Ukraine (Tarashchuk, 1965) and Turkey (Rückert-Ülkümen et al., 2002; Rückert-Ülkümen and Yigitbaş, 2006). Most of those discoveries were described using open nomenclature, except Silurus joergi Gaudant, 2015 from the late Miocene of Höwenegg locality in Germany.

Here we describe catfish material from late Miocene through Pleistocene strata of southern Ukraine and Russia. Those remains document the presence of at least three species of the genus Silurus and one species of the genus Heterobranchus. This study provides new data on species diversity of catfishes in Southeastern Europe in the range of late Miocene - Pleistocene with inference to their past diversity and biogeographical history of European catfishes.

\section{MATERIAL AND METHODS}

The material under study is represented by disarticulated bones, housed in the Department of Paleontology of the National Museum of Natural History (NMNHU-P), National Academy of Sciences of Ukraine (collection No. 4, 29, 33, 37, 38, $41,42,45,53)$. It is derived from 26 localities in the territory of Southern Ukraine and the Russian Fed- eration (Figure 1). The majority of those localities yielded heterochronous layers with numerous catfish remains, dated as the late Miocene, Pliocene and Pleistocene (Table 1). Their ages were established based on published accounts of small mammals (Nesin and Nadachowski, 2001; Krochmal and Rekovets, 2010; Nesin, 2013) and are consistent with biostratigraphic dates derived from the accompanying fauna. Identification of the catfish bones is based on comparative material from the osteological collections of NMNHU-P and PIN as well as descriptions and illustrations in the literature (see Appendix). The taxonomic hierarchy follows Nelson (2006) and Ferraris (2007). Correlation of the Eastern Paratethys stages follows Topachevsky et al. (1997, 1998), Nesin and Nadachowski (2001). General stratigraphic scale of Quaternary rocks (Head et al., 2015) has been used for correlation of the Pleistocene sediments containing catfish fossils. Measurements were taken with a digital caliper, with $0.1 \mathrm{~mm}$ precision. Bone terminology follows Sytchevskaya (1989), Lepiksaar (1994), Otero and Gayet (2001), and Böhme (2002).

\section{Institutional Abbreviations}

HU, Howard University, USA; IAUS, Islamic Azad University Shiraz, Iran; IZ, Schmalhausen Institute of Zoology of the National Academy of Sciences of Ukraine; NMNHU-P, Department of Paleontology of the National Museum of Natural History of the National Academy of Sciences of Ukraine; PIN, Borissiak Paleontological Institute at the Russian Academy of Sciences; SMNHS, State Museum of Natural History Stuttgart, Germany; UNAM, Universidad Nacional Autónoma de México; UPW, Wroclaw University of Environmental and Life Sciences, Poland.

\section{SYSTEMATIC PALAEONTOLOGY}

Order SILURIFORMES Cuvier, 1816

Family CLARIIDAE Bonaparte, 1846

Genus HETEROBRANCHUS Geoffroy-Saint-

Hilaire, 1809

†Heterobranchus austriacus Thenius, 1952

Figure 2.1-10

1952 Heterobranchus austriacus sp. nov.; Thenius, abb. 3.

1954 Heterobranchus austriacus Thenius, 1952; Weinfurter, plate 6, figures 12-14.

2002 Heterobranchus austriacus Thenius, 1952; Böhme, plate 4, figures 1-3, 6 .

Material. pectoral-fin spines - 34 left, 34 right (NMNHU-P 33/570-637, Mykhailivka 2), 8 left, 


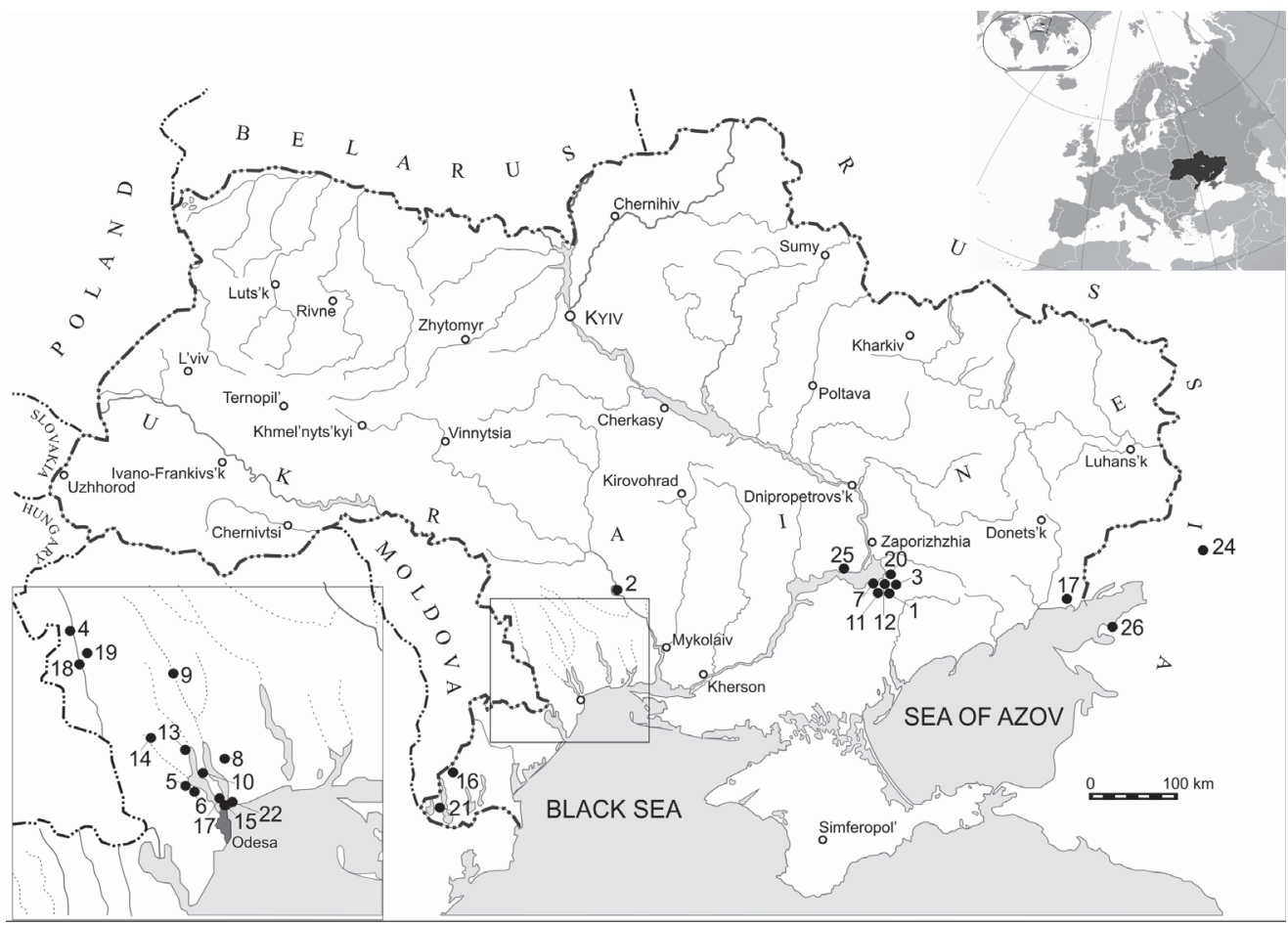

FIGURE 1. Investigated localities with late Miocene, Pliocene and Pleistocene catfish remains. 1, Popovo. 2, Mykhailivka. 3, Lobkovo. 4, Frunzovka. 5, Palievo. 6, Otradovo. 7, Lysa Gora. 8, Kubanka. 9, Novoelizavetovka. 10, Cherevichne. 11, Vasylivka. 12, Verkhnya Krynitsya. 13, Egorovka. 14, Novoukrainka. 15, Pontian lectostratotype. 16, Vinogradovka. 17, Nerubaiske. 18, Trudomirovka. 19, Novopetrovka. 20, Kamenskoe. 21, Kotlovina. 22, Shkodova Gora. 23, Shirokino. 24, Obukhovka. 25, Novokyivka. 26, Semibalka.

12 right (NMNHU-P 41/2891-2893, 2908-2924, Frunzovka 2), 5 left, 1 right (NMNHU-P 41/34593464, Palievo), 2 left (NMNHU-P 41/3563-3564, Otradovo), 4 right (NMNHU-P 41/3731-3734, Kubanka 2), 1 left, 1 right (NMNHU-P 41/34123413, Novoelizavetovka 2).

Description. Slender pectoral-fin spine (Figure $2.1,2.4,2.6)$ is slightly curved posteriorly. There are numerous blunt denticulations along the postaxial margin of the shaft. The regular denticulations are weak and directed perpendicular to the shaft. The anterior margin of the shaft has small rounded (tear-shaped) denticulations (Figure 2.1, 2.6, 2.9). A well-developed shallow groove is situated proximally along the posterior margin of the shaft (Figure 2.2). Edges of the pectoral-fin spine are narrow and laterally compressed; therefore the shaft is lenticular in cross-section. The broad cleithral surface (Figure 2.3, 2.5, 2.7, 2.10) is crescent-shaped with numerous frequent ridges, which are characteristic of the genus Heterobranchus (Böhme, 2002). The three processes are designated as dorsal, ventral and anterior (Diogo et al., 2001) or dorsolateral, ventrolateral and axial (Otero and Gayet, 2001), respectively. The ventrolateral3 process is large, with a proximally directed rounded tip; the dorsolateral process is mediumsized and the axial process is smooth. A right pectoral-fin spine with an abnormal accrete intravital fracture (Figure 2.8) was obtained from the Mykhailivka 2 locality.

Remarks. The pectoral-fin spines are similar in overall morphology and size to those identified as Heterobranchus austriacus from the VösendorfBrunn and Sandberg in Austria (Gaudant, 1994; Böhme, 2002). However, pectoral-fin spines from the late Miocene of Ukraine have a larger ventrolateral process and more regular denticulations at the postaxial margin.

Family SILURIDAE Cuvier, 1816

Genus SILURUS Linnaeus, 1758

†Silurus spinosus $\mathrm{n}$. sp.

Figure 3.1-13

zoobank.org/08CBCE52-6752-400C-ABD4-B95290CC2AE5

Etymology. The name refers to the unusual multiserial denticulations on the pectoral-fin spine.

Type material. Holotype NMNHU-P 29/1747, complete left pectoral-fin spine (Figure 3.1-5). Paratypes NMNHU-P 29/1748, 1749, 1750 right 
TABLE 1. Stratigraphic distribution of investigated localities with catfish remains.

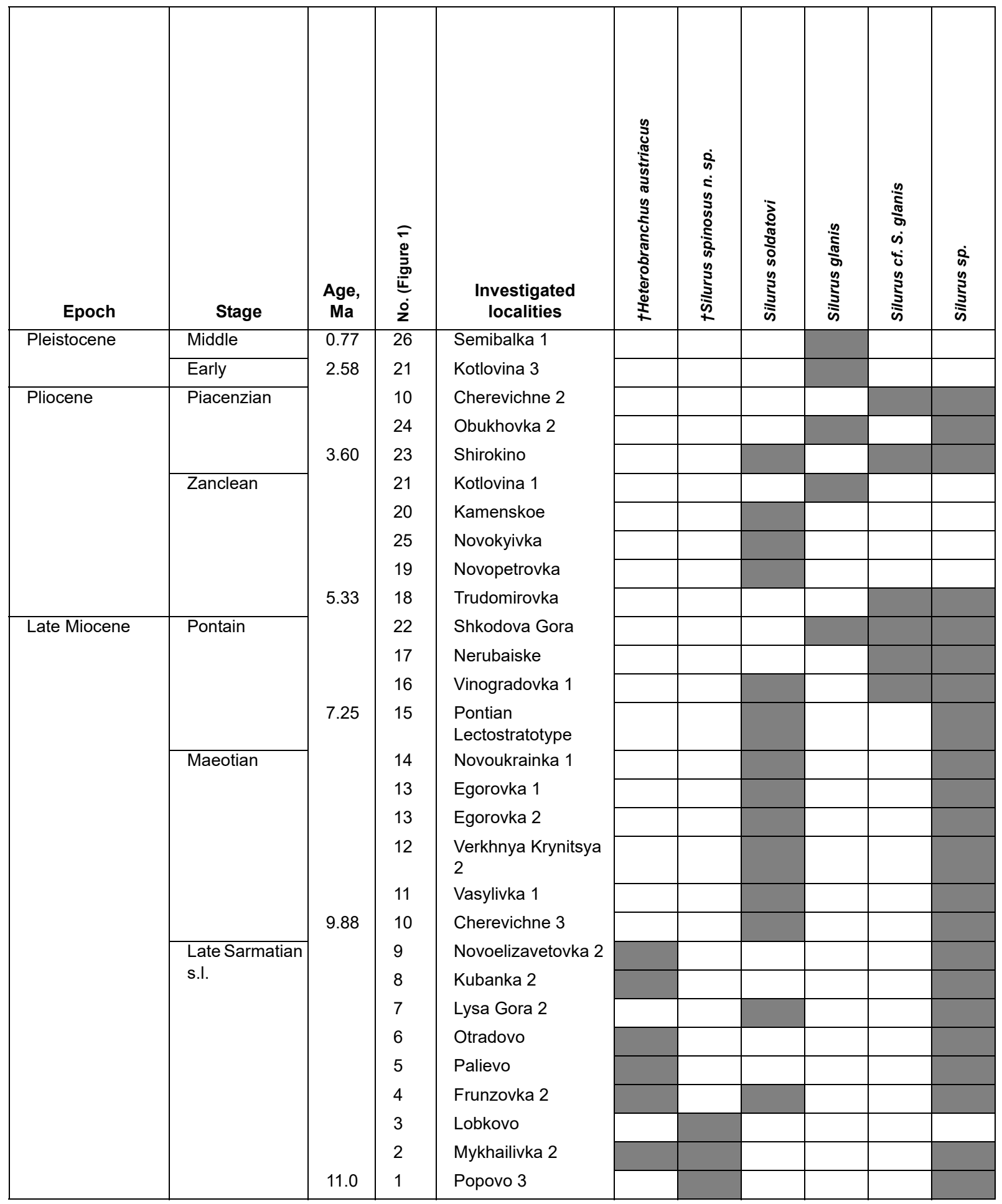

pectoral-fin spines, 29/1756 parasphenoid, 29/ 1906 praemaxilla, 29/1911 quadrate, 29/4002 right dentary, 29/1852 articular, and 29/1814 cleithrum. Additional material. 5 praemaxillae, 1 articular, 5 quadrates, 30 dentaries, 9 cleithra, 72 proximal and 42 distal portions of pectoral-fin spines
(NMNHU-P 29/1751-1755, 1757-1813, 1815-1851, 1853-1905, 1907-1910, 1912-1917, Popovo 3); 8 dentaries, 17 proximal and 13 distal portions of pectoral-fin spines (NMNHU-P 29/3997-4001, 4003-4035, Lobkovo); and 6 proximal portions of 

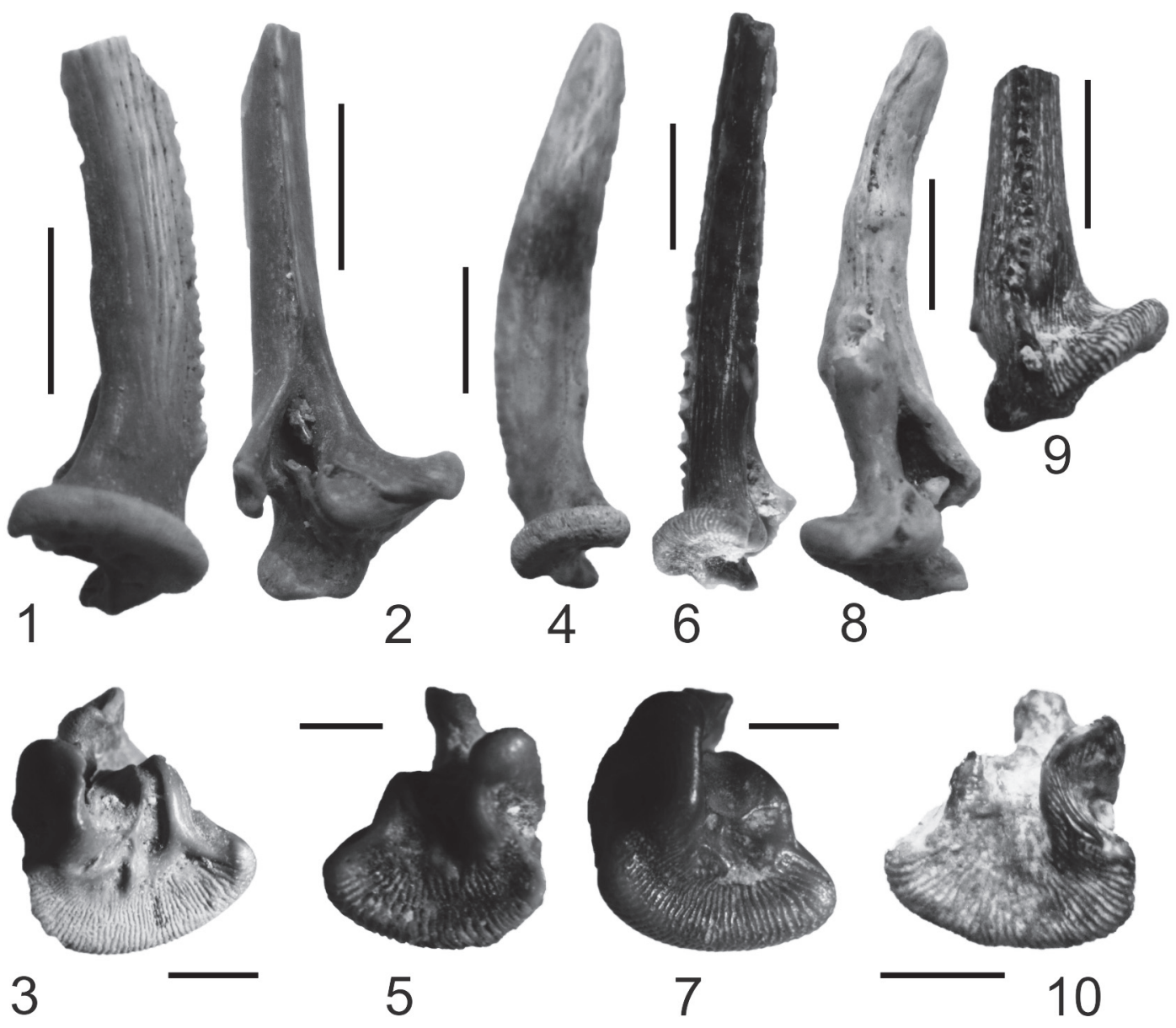

FIGURE 2. Isolated bones assigned to †Heterobranchus austriacus Thenius, 1952. 1-3, left pectoral-fin spine (NMNHU-P 33/570, Mykhailivka 2): dorsal view (1), ventral view (2), proximal articulation surface (3). 4-5, right pectoral-fin spine (NMNHU-P 41/3732, Kubanka 2): dorsal view (4), proximal articulation surface (5). 6-7, right pectoral-fin spine (NMNHU-P 41/2891, Frunzovka 2): dorsal view (6), proximal articulation surface (7). 8, right pectoral-fin spine with wrong accrete fracture (NMNHU-P 33/574, Mykhailivka 2), lateral view. 9-10, right pectoral-fin spine (NMNHU-P 41/2908, Frunzovka 2): lateral view (9), proximal articulation surface (10). Scale bars equal $5 \mathrm{~mm}$ (Figure 2.1-2, 2.4, 2.6, 2.8-9) and $2 \mathrm{~mm}$ (Figure 2.3, 2.5, 2.7, 2.10).

pectoral-fin spines (NMNHU-P 638-643, Mykhailivka 2).

Type locality. Popovo 3, near Vasylivka, Zaporizhzhia region, Southern Ukraine (Figure 1).

Geological age and distribution. late Miocene, late Sarmatian of Southeastern Europe.

Diagnosis. Silurus spinosus n. sp. differs from other species of the genus Silurus in the following unique combination of characters: (1) multiserial denticulations at the lateral margin of pectoral-fin spine shaft; (2) projecting flattened crests on the ventral surface of medial part of the parasphenoid; (3) rounded and shortened facies articularis quadrati on the articular; and (4) narrow oral surface of the dentary with 3-5 tooth rows, weakly developed dental shelf and widened symphysis.
Description. Pectoral-fin spine (Figure 3.1-7) is extended in length and tapered to a point at the distal end. The surface of the bone has distinct longitudinal grooves. The shaft is lenticular or rounded in cross-section, with a deep furrow on the anterior plane, starting from the base and continuing to the tip. The base of the pectoral-fin spine is moderately widened and slightly flattened (arched in some specimens), deflected medially from the shaft. There are usually 3 , rarely $4-5$, rows of weak denticulations. The denticulations extend basally to the level of approximately $1 / 5$ of the shaft length and point in different directions. The medial margin of the shaft has strong, pointed, conical and slightly curved denticulations. The ratio of width to length is near 1:4-1:5. The dorsal process of the spine base 

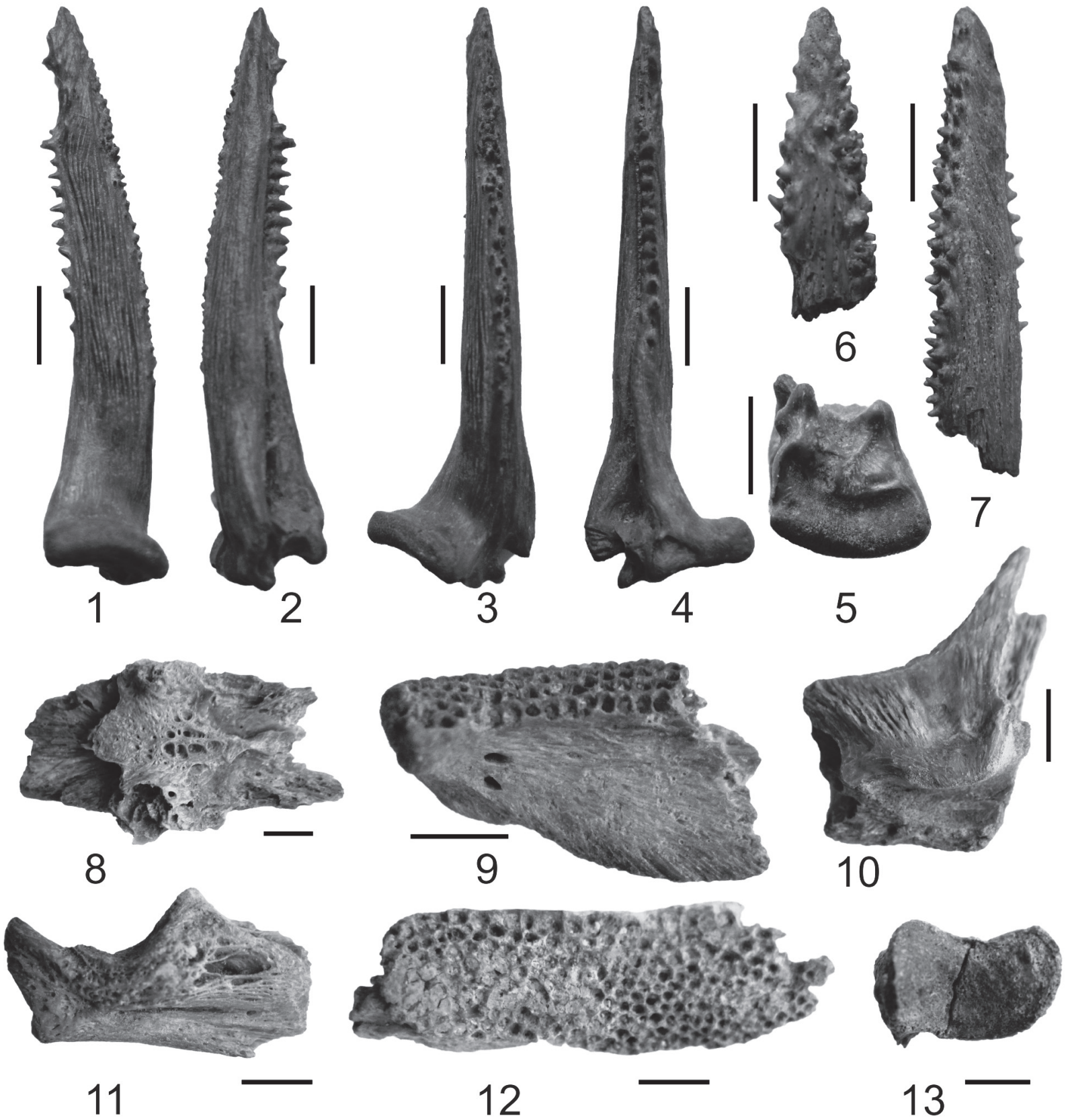

FIGURE 3. Isolated bones assigned to †Silurus spinosus n. sp. 1-5, holotype, left pectoral-fin spine (NMNHU-P 29/ 1747, Popovo 3): dorsal view (1), ventral view (2), medial view (3), lateral view (4), proximal articulation surface (5). 67, distal fragments of pectoral-fin spines (NMNHU-P 29/4034-4035, Lobkovo). 8, medial part of parasphenoid (NMNHU-P 29/1756, Popovo 3), dorsal view. 9, right dentary (NMNHU-P 29/4002, Lobkovo), medial view. 10, symphysal fragment of cleithrum (NMNHU-P 29/1814, Popovo 3), lateral view. 11, articular (NMNHU-P 29/1852, Popovo 3), lateral view. 12, praemaxilla (NMNHU-P 29/1906, Popovo 3), ventral view. 13, articular facet of quadrate (NMNHU-P 29/1911, Popovo 3), anterior view. Scale bars equal $10 \mathrm{~mm}$.

(Figure 3.5) has a swollen margin, the ventral process is fairly wide and lobate, and the anterior process is small and rounded. The longest spine examined was $45.2 \mathrm{~mm}$ (holotype $37.0 \mathrm{~mm}$ ). The parasphenoid (Figure 3.8) is an arched bone, com- pressed dorsoventrally, with two flattened crests projecting on the ventral surface. The posterior part of the parasphenoid is widened caudally and the carotid grooves are high and wide. The dentary (Figure 3.9) is characterized by a narrow oral sur- 
face (only 3-5 tooth rows), weakly developed dental shelf and widened symphysis. Dentary teeth are small, with conical crowns and circular bases. The praemaxilla (Figure 3.12) is flattened, elongated and contains numerous rows of small teeth. The cleithrum has a deep cavity for the articular head of the pectoral-fin spine (Figure 3.10) that is uniform in width and medially curved in a smooth arc. The articular facet (facies articularis quadrati) on the articular bone (Figure 3.11) is wide anteriorly and narrow posteriorly. The bone wall is high $\left(45^{\circ}\right)$, with a wide ventroposterior angle. The quadrate (Figure 3.13 ) is robust; its articular facet is nearly rectangular, with smoothly rounded edges.

Remarks. The various disarticulated bones that comprise the paratype series and additional material were assigned to †Silurus spinosus n.sp. based on their clear differences from the comparable elements of the only other catfishes (Silurus soldatovi, Silurus sp.) currently known from the outcrop. Differences in those elements are not emphasized in the systematic discussion, below, inasmuch as the pectoral-fin spine differences are sufficient to establish the species as new and the associated bones are necessarily only hypothesized to be those of $\dagger S$. spinosus.

Systematic discussion. The only other named extinct species of catfish that is currently assigned to Silurus is Silurus joergi Gaudant, 2015, from the Miocene strata of Höwenegg (Germany). The pectoral-fin spine of Silurus joergi is comparably shorter, much more robust and clearly rounded in cross-section. There are short blunt denticulations on the medial margin, which are slightly shifted in lateral projection (Gaudant, 2015).

Of the extant species of the genus. †Silurus spinosus n.sp. is most similar in morphology to Silurus soldatovi Nikolsky and Soin, 1948, and Silurus cochinchinensis Valenciennes, 1839, in curvature of the pectoral-fin spine. However, the spine of $S$. soldatovi has only numerous uniserial small weak denticulations on the medial and lateral margins, and the spine of S. cochinchinensis has a deep notch at the base and characterized by the presence of large flattened accrete denticulations only on the medial margin of the shaft, which becomes very thin (Kobayakawa, 1989). The pectoral-fin spine of the new species is significantly narrower distally and is characterized by a less swollen dorsal process and less regular uniserial denticulations on both margins of the shaft than that of Silurus aristotelis (Agassiz, 1856), (Kobayakawa, 1989). The pectoral-fin spine of Silurus biwaensis (Tomoda, 1961), in addition to features mentioned above, is comparably narrower (Kobayakawa, 1989). Other species of the genus Silurus are even less similar to †Silurus spinosus n. sp. For example, pectoral-fin spine of Silurus glanis Linnaeus, 1758 has more robust articular processes and yielded long accrete denticulations on the medial margin; at the same time there are no any denticulations at the lateral margin of the shaft. The pectoral-fin spine of Silurus grahami Regan, 1907 has a wider base and ventral process, a naked medial margin and small weak uniserial denticulations on the lateral margin (Kobayakawa, 1989). Such denticulations are completely absent on the pectoralfin of Silurus microdorsalis (Mori, 1936), with the exception of a few of them at the top of the shaft (Kobayakawa, 1989).

Silurus soldatovi Nikolsky and Soin, 1948

Figure 4.1-28

1962 Parasilurus sp.; Tarashchuk, p. 10.

1965 Parasilurus sp.; Tarashchuk, p. 77, figure 1.

1980 Parasilurus cf. asotus (Linnaeus, 1758); Sytchevskaya, plate 13, figures 3-7.

1989 Silurus cf. soldatovi Nikolsky and Soin, 1948; Sytchevskaya, plate 24, figures 4-6.

2011 Silurus sp.; Kovalchuk, p. 134, figure 2.1-2.3.

Material. pectoral-fin spines - 2 prox., 3 dist. (NMNHU-P 41/2894-2898, Frunzovka 2), 1 prox., 2 dist. (NMNHU-P 29/551-553, Lysa Gora 2), 2 prox., 2 dist. (NMNHU-P 41/5376-5379, Novoelizavetovka 3), 8 prox., 1 complete (NMNHU-P 41/ 4282-4290, Egorovka 1), 2 prox. (NMNHU-P 38/ 1953-1954, Novoukrainka 1), 1 prox. (NMNHU-P 41/2454, Pontian lectostratotype), 1 prox. (NMNHU-P 41/2730, Vinogradovka 1); 1 cleithrum, pectoral-fin spines -3 prox., 1 dist. (NMNHU-P 45/ 5662-5666, Cherevichne 3); 1 articular bone, 5 dentary fragments, 3 cleithra, pectoral spines -4 prox., 7 dist. (NMNHU-P 29/1221-1240, Vasylivka 1); 4 dentary fragments, 1 cleithrum, pectoral-fin spines - 3 prox., 2 dist. (NMNHU-P 29/662-671, Verkhnya Krynitsya 2); 3 cleithra, pectoral-fin spines - 13 prox., 12 dist. (NMNHU-P 41/44324459, Egorovka 2); 1 pectoral-fin spine (NMNHU-P 37/736, Novopetrovka); 6 articulars, 23 dentaries, 5 quadrates, 22 cleithra, pectoral-fin spines -61 prox., 34 dist., 20 isolated centra (NMNHU-P 42/ 197-213, 215, 217-236, 238-240, 242-260, 441, 478, 488-499, 501-502, 504, 509, 590, 616- 618, $621-626,659,660-662,664,667,674,677-699$, $779,784-786,819,885,1219,1223,1249,1253-$ 1296, Kamenskoe); 2 proximal portions of pectoralfin spines (NMNHU-P 29/3971-3972, Shirokino); 3 dentaries, 24 articulars, 44 cleithra, 27 centra of Weberian apparatus, 60 proximal and 28 distal por- 


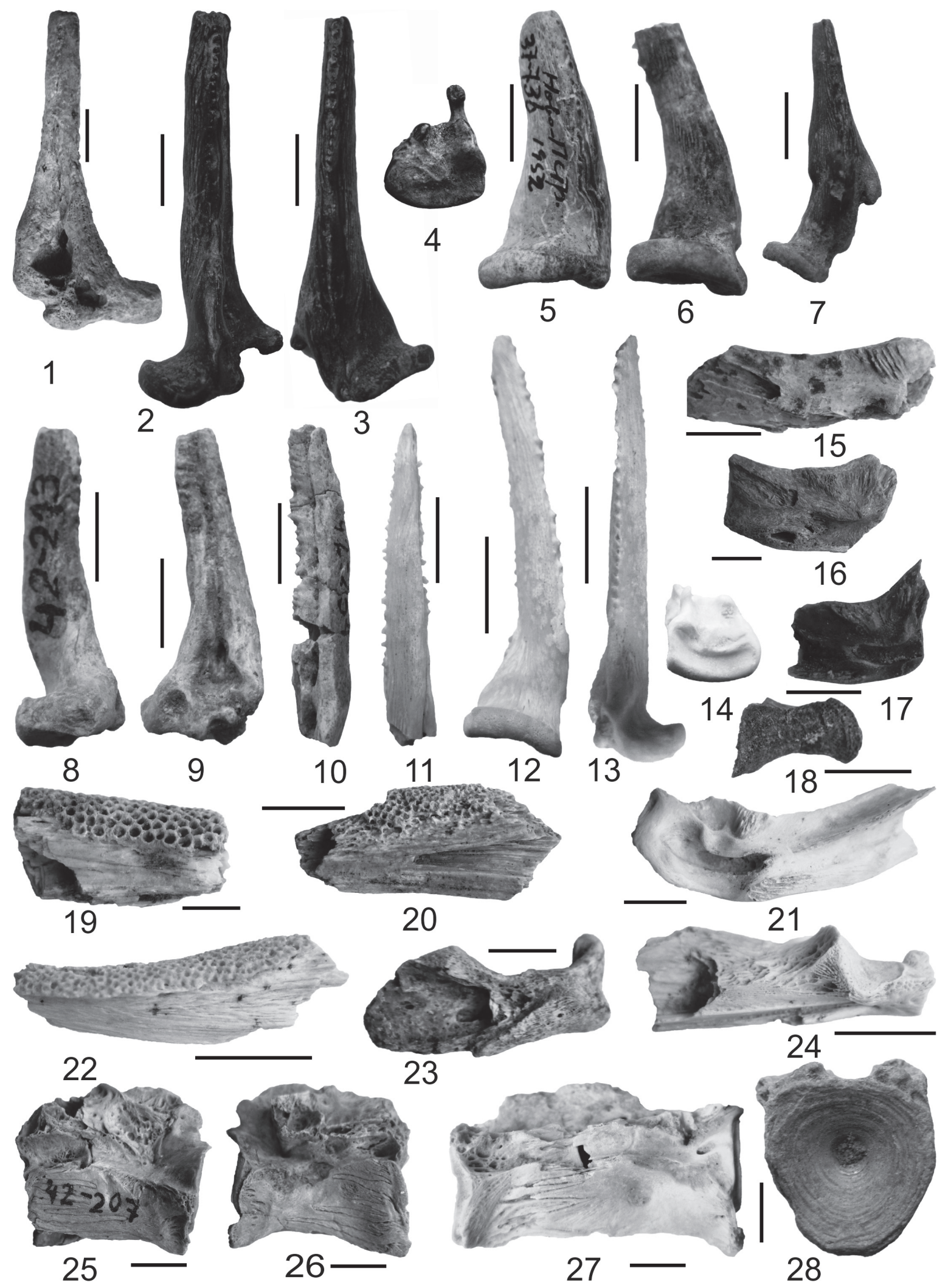


tions of pectoral-fin spines (NMNHU-P 53/45074692, Novokyivka).

Description. Pectoral-fin spine (Figure 4.1-14) is straight or slightly curved. Articular head of the bone is elongated and flattened, with small medial and ventral processes and a wide anterior process. The medial and lateral margins of the shaft have numerous uniserial small weak denticulations, and additional weaker denticulations along medial edge. Cleithrum (Figure 4.15-17, 4.21) are generally fragments, mostly represented by a wide medial portion. Wide crest of horizontal part of the cleithrum (crista articularis) is well-developed and extended medially. Cavity for the articular head of the pectoral-fin spine is narrow anteriorly and widened posteriorly. Slightly gracile quadrate (Figure 4.18) has a low and narrow articular facet. Dentary (Figure 4.19-20, 4.22) is triangular in cross-section, with moderately wide rounded symphysal edge and convex oral surface. Articular bone (Figure 4.23-24) has a low wall $\left(35-40^{\circ}\right)$ with a narrow and elongated facet articularis quadrati. Ventral surface of articular is nearly straight, with a rounded ventral posterior angle. Weberian centrum (Figure 4.2527 ) is short and high, its articular surface is deepened, higher than wide, with the opening for the spinal cord is displaced dorsally; posterior surface is slightly deeper than wide and ventrally narrowed, with a more central position of the opening for the spinal cord. Abdominal centrum (Figure 4.28) is round in end view and nearly rectangular in crosssection.

Remarks. The numerous pectoral-fin spines and other bones of this species, from localities different ages appear to belong to both juvenile and adult individuals. They are very similar in morphology to those of extant Silurus soldatovi, as well as Silurus cf. soldatovi from the late Miocene and Pliocene of Western Mongolia and Kazakhstan (Sytchevskaya, 1989), and we confidently assign them to that species.

\section{Silurus glanis Linnaeus, 1758}

Figure 5.1-12

1989 Silurus glanis; Kobayakawa, p. 158, figure 4d.

2015 Silurus glanis; Kovalchuk et al., p. 54, figure 4.

2015 Silurus glanis; Kovalchuk, p. 205, figure 3.

Material. 1 dentary fragment, 2 isolated jaw teeth, 1 cleithrum, 1 distal and 4 proximal portions of pectoral-fin spines (NMNHU-P 41/2529-2536, Kotlovina 1); 1 dentary fragment, 1 articular bone, 1 quadrate, 3 parasphenoids, cranial bones, 1 cleithrum, 4 pectoral-fin spines, 2 abdominal centra (NMNHU-P 41/52, 218, 543, 545, 579, 609, 615, 617-620, 623-624, 626, 717, 1137, 1233, Shkodova Gora); pectoral-fin spines -3 prox., 1 dist. (NMNHU-P 53/4693-4696, Obukhovka 2), 4 prox., 1 dist. (NMNHU-P 41/2537-2541, Kotlovina 3), 1 prox. (NMNHU-P 53/4697, Semibalka 1).

Description. Massive pectoral-fin spine (Figure $5.1-2$ ) is straight or slightly curved in medial projection. The bone is oval or rounded in cross-section, with a weakly expanded and dorsoventrally compressed base (Figure 5.3). Medial margin of the shaft yielded long concrescent denticulations (Figure 5.4), located on distal one-third of the spine. Lateral margin of the shaft is usually smooth. Dorsal process of the spine has narrow edge; ventral process is small-sized, anterior is wide and flattened. Parasphenoid (Figure 5.9-10) is robust and wide (especially in its medial part), trapezoidal in cross-section. Proximal and distal portions of the

FIGURE 4 (previous page). Isolated bones assigned to Silurus soldatovi Nikolsky and Soin, 1948. 1, left pectoral-fin spine (NMNHU-P 41/2894, Frunzovka 2), medial view. 2-4, right pectoral-fin spine (NMNHU-P 41/2454, Pontian lectostratotype): lateral view (2), medial view (3), proximal articulation surface (4). 5, left pectoral-fin spine (NMNHU-P 37/ 736, Novopetrovka), dorsal view. 6, left pectoral-fin spine (NMNHU-P 41/4432, Egorovka 2), dorsal view. 7, left pectoralfin spine with wrong accrete fracture (NMNHU-P 41/4457, Egorovka 2), medial view. 8-9, right pectoral-fin spine (NMNHU-P 42/213, Kamenskoe): dorsal view (8), medial view (9). 10, distal part of pectoral-fin spine (NMNHU-P 42/ 254, Kamenskoe), ventral view. 11, distal part of pectoral-fin spine (NMNHU-P 53/4508, Novokyivka), dorsal view. 1214, left pectoral-fin spine (NMNHU-P 53/4507, Novokyivka): dorsal view (12), lateral view (13), proximal articulation surface (14). 15, symphysal part of cleithrum (NMNHU-P 29/1223, Vasylivka 1), lateral view. 16, fragment of cleithrum (NMNHU-P 29/664, Verkhnya Krynitsya 2), lateral view. 17, symphysal part of cleithrum (NMNHU-P 41/4458, Egorovka 2), lateral view. 18, articular facet of quadrate (NMNHU-P 42/784, Kamenskoe), anterior view. 19, fragment of left dentary (NMNHU-P 29/1238, Vasylivka 1), lateral view. 20, fragment of right dentary (NMNHU-P 42/885, Kamenskoe), lateral view. 21, right cleithrum (NMNHU-P 53/4614, Novokyivka), lateral view. 22, left dentary (NMNHU-P 53/4610, Novokyivka), lateral view. 23, right articular (NMNHU-P 29/1237, Vasylivka 1), medial view. 24, right articular (NMNHUP 53/4593, Novokyivka), medial view. 25-26, Weberian centrum (NMNHU-P 42/207, Kamenskoe), lateral view. 27, Weberian centrum (NMNHU-P 53/4580, Novokyivka), lateral view. 28, abdominal centrum (NMNHU-P 42/1249, Kamenskoe), anterior view. Scale bars equal $10 \mathrm{~mm}$ (Figure 4.1-5, 4.8-16, 4.18, 4.20-26) and $5 \mathrm{~mm}$ (Figure 4.6-7, 4.17, 4.19, 4.27-28). 


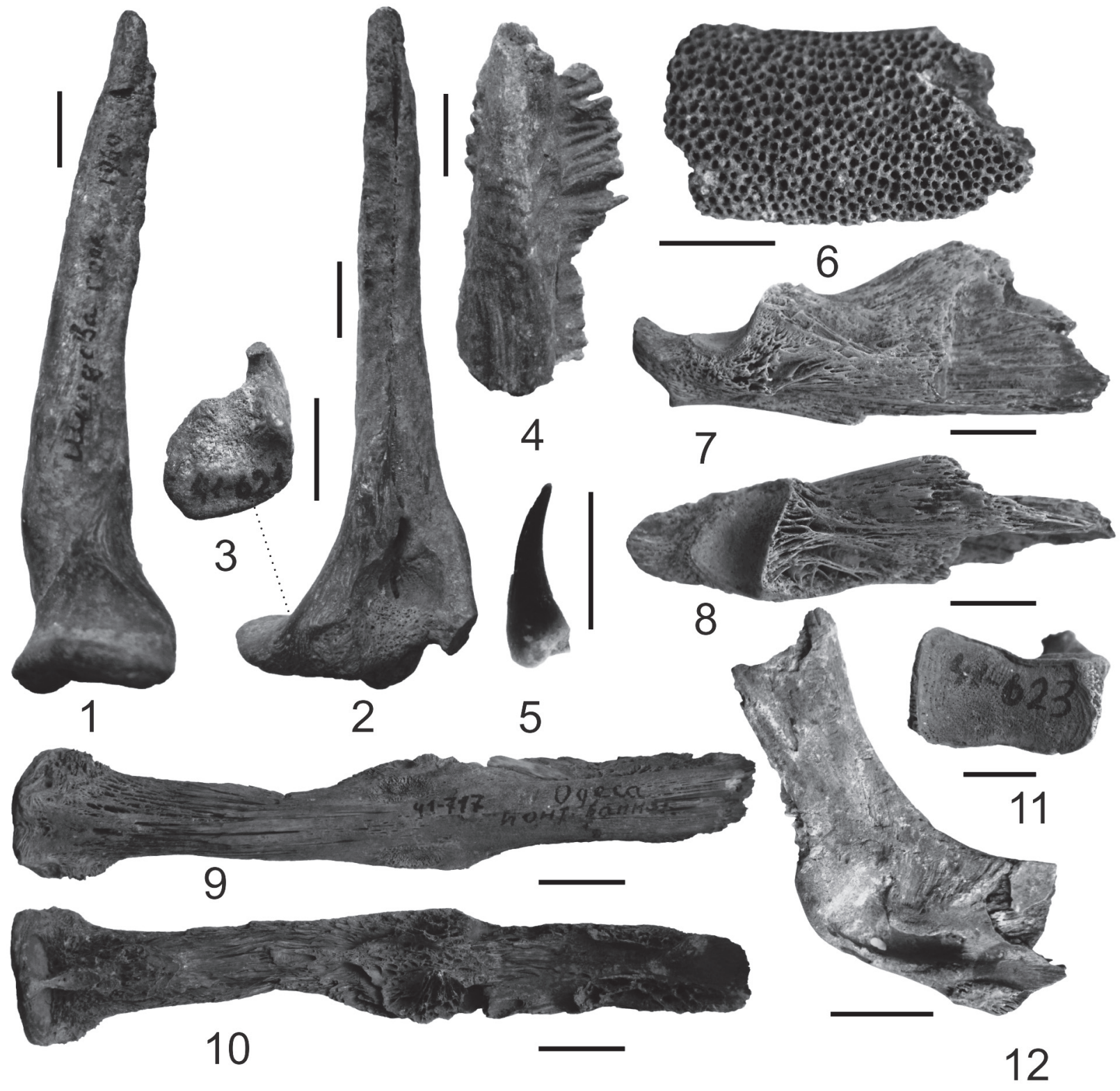

FIGURE 5. Isolated bones assigned to Silurus glanis Linnaeus, 1758. 1-4, right pectoral-fin spines (NMNHU-P 41/ 609, 621, Shkodova Gora): dorsal view (1), lateral view (2), proximal articulation surface (3), fragment of the shaft with denticulations (4). 5, isolated jaw tooth (NMNHU-P 41/2530, Kotlovina 1), lateral view. 6, fragment of left dentary (NMNHU-P 41/52, Shkodova Gora): dorsal view. 7-8, right articular (NMNHU-P 41/626, Shkodova Gora): lateral view (7), dorsal view (8). 9-10, parasphenoid with basioccipital bone (NMNHU-P 41/717, Shkodova Gora): ventral view (9), dorsal view (10). 11, fragment of quadrate (NMNHU-P 41/623, Shkodova Gora), anterior view on the articular facet. 12, fragment of cleithrum (NMNHU-P 41/615, Shkodova Gora), lateral view. Scale bars equal $20 \mathrm{~mm}$ (Figure 5.9-10, 5.12), $10 \mathrm{~mm}$ (Figure 5.1-4, 5.6-8, 5.11) and $5 \mathrm{~mm}$ (Figure 5.5).

bone are slightly expanded. Ventral surface (Figure 5.9 ) is smooth, dorsal surface with well-developed carotid grooves (Figure 5.10). Wide articular facet of quadrate is nearly rectangular (Figure 5.11), with caudally deflected posterior process. Articular bone (Figure 5.7-8) is massive, with a partly broken distal end. Anterior part of its oval articular facet is expanded, and the posterior part is smoothly rounded. Dentary (Figure 5.6) has flattened dentigerous surface yielding numerous tooth rows $(n=17)$. The lateral surface of the dentary has welldeveloped sensory-canal pores. Jaw tooth (Figure 5.5 ) is small and conical; its crown is posteriorly curved, circular at the base and pointed at the tip. 
Cleithrum (Figure 5.12) has high and robust ascending process. Its long vertical branch is deflected posterodorsally and compressed at the base. The cavity for the articular part of the pectoral spine is anteriorly narrowed and posteriorly expanded.

Remarks. All described bones are morphologically identical to those in extant Silurus glanis. Judging by their sizes, it appears that they belonged to relatively large adult individuals.

Silurus cf. S. glanis Linnaeus, 1758

Figure 6.1-7

Material. Four proximal portions of pectoral-fin spines, 1 centrum (NMNHU-P 41/2731-2735, Vinogradovka 1); 2 centra (NMNHU-P 53/4698-4699, Nerubaiske); 2 centra (NMNHU-P 37/797, 2257, Trudomirovka); 1 fragment of parasphenoid, 2 centra (NMNHU-P 41/680, 876, 1165, Shkodova Gora); 1 centrum (NMNHU-P 29/3973, Shirokino); 1 centrum (NMNHU-P 45/4052, Cherevichne 2).

Description. Pectoral-fin spine is rounded and characterized by an expanded flattened base and small blunt denticulations on the medial margin of the shaft. Dorsal process of articular base is medium-sized, whereas the ventral and anterior processes are small with conical tips. Parasphenoid (Figure 6.7) is represented by its medial part, anterior and posterior ends are completely broken. The bone is wide, with well-developed and clearly visible carotid grooves on its surface. Centra (Figure 6.1-5) are oval or rounded in end view and rectangular in lateral view. Most have shallow articular surfaces at their anterior and posterior ends. Large abdominal centra (Figure 6.1,6.3-6) are typically wider than high or long, although sometimes height and width are comparable. Wide and robust parapophyses are developed on the dorsal and lateral sides of those bones. Caudal centrum (Figure 6.2) is higher or longer than wide.

Remarks. The centra and other bone fragments described above are similar to those in Silurus glanis based on their characteristic morphology, shape and surface sculpturing. Because of their poor preservation, however, we only cautiously assign them to that species.

\section{Silurus sp.}

2014 Silurus sp.; Kovalchuk et al., p. 50, figure 6.

Material. 544 centra (NMNHU-P 29/1918-2461, Popovo 3); 2 fragments of cleithra, 8 distal portions of pectoral-fin spines, 47 centra (NMNHU-P 33/ 644-722, Mykhailivka 2); 5 dentaries, 4 praemaxilla fragments, 1 proximal and 3 distal portions of pectoral-fin spines, 6 centra (NMNHU-P 29/39743992, Lobkovo); 3 dentary fragments, 1 (articular) portion of cleithrum, 5 centra (NMNHU-P 41/28992907, Frunzovka 2); pectoral-fin spines -3 prox., 3 dist., 1 centrum (NMNHU-P 41/3465-3471, Palievo); 2 distal portions of pectoral-fin spines (NMNHU-P 41/3565-3566, Otradovo); 3 praemaxilla fragments, 1 dentary, 2 centra (NMNHU-P 29/ 554-559, Lysa Gora 2); 2 dentary fragments, 2 jaw teeth, 4 centra (NMNHU-P 41/3735-3742, Kubanka 2); 2 distal portions of pectoral-fin spines, 15 centra (NMNHU-P 41/3414-3430, Novoelizavetovka 2); 1 dentary fragment, 1 jaw tooth, 22 centra (NMNHU-P 45/5666-5689, Cherevichne 3); 2 cleithra, 1 proximal portion of pectoral-fin spine, 152 centra (NMNHU-P 29/1241-1395, Vasylivka 1); 6 dentary fragments, pectoral-fin spines -6 prox., 6 dist., 343 centra (NMNHU-P 29/672-1032, Verkhnya Krynitsya 2); 2 praemaxilla and 22 dentary fragments, 4 isolated teeth, 1 cleithrum, 9 distal portions of pectoral-fin spines (NMNHU-P 41/ 4460-4497, Egorovka 2); 1 praemaxilla and 19 dentary fragments, 12 distal portions of pectoral-fin spines (NMNHU-P 41/4291-4322, Egorovka 1); 1 proximal and 4 distal portions of pectoral-fin spines, 4 centra (NMNHU-P 38/1955-1963, Novoukrainka 1); 5 isolated teeth, 5 fragments of pectoral-fin spines (NMNHU-P 41/2455-2464, Pontian lectostratotype); 1 dentary fragment, 1 centrum (NMNHU-P 41/2736-2737, Vinogradovka 1); 2 centra (NMNHU-P 53/4700-4701, Nerubaiske); 7 centra (NMNHU-P 37/737-739, 797-799, 2558, Trudomirovka); 1 cranial bone, 1 centrum, 2 proximal portions of pectoral-fin spines (NMNHU-P 29/ 3993-3996, Shirokino); 1 praemaxilla fragment, 1 proximal portion of pectoral-fin spine (NMNHU-P 53/4707-4708, Obukhovka 2); 41 centra (NMNHUP 41/582, 588, 680, 697-699, 883, 887, 890, 1165, $1168,1170-1171,1182-1183,1186,1197,1213$, 1218, 1234, 1238, 4709-4728, Shkodova Gora); 156 centra (NMNHU-P 53/4729-4884, Novokyivka); 1 centrum (NMNHU-P 45/4052, Cherevichne 2).

Description. All examined bones are represented by small fragments, for which it is not possible to measure or describe them here. The remains do not appear to be those of Heterobranchus and are comparable in morphology with those that we interpreted as belonging to the genus Silurus. They are not, however, sufficiently recognizable to be assigned to any of the species. 

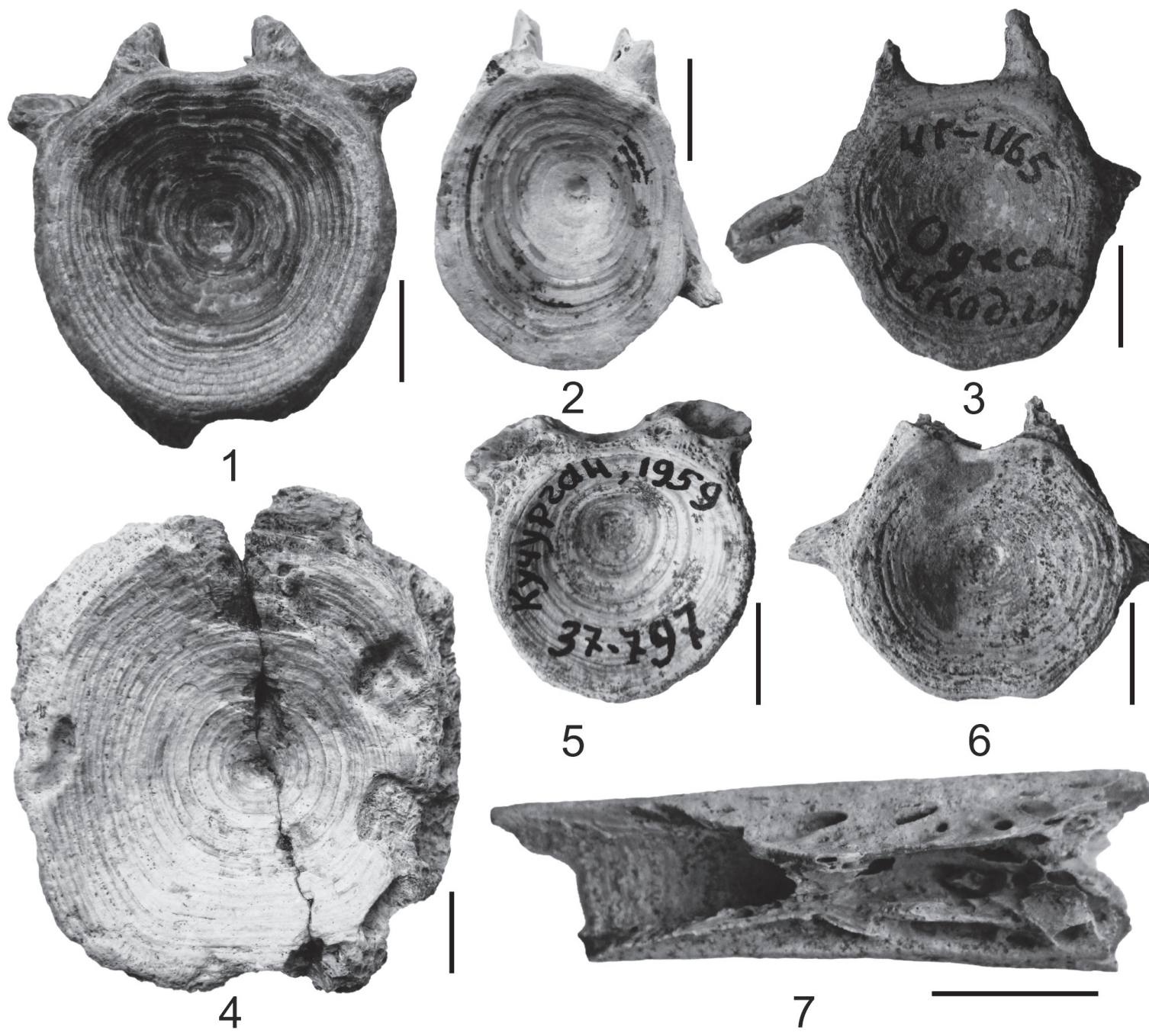

5

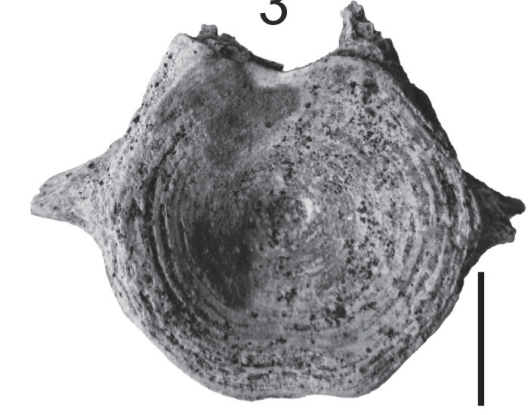

6

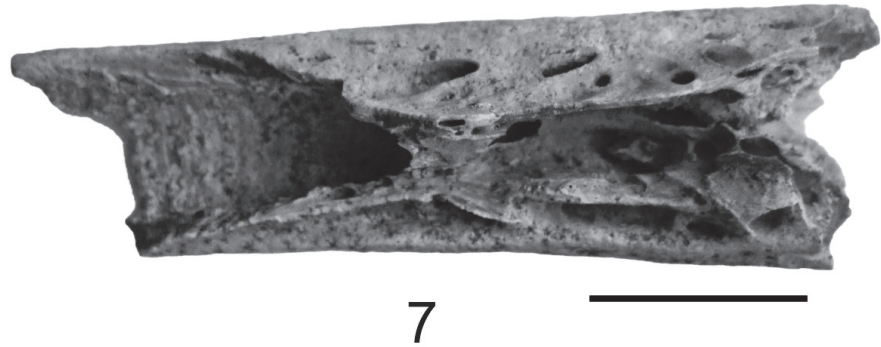

FIGURE 6. Isolated bones assigned to Silurus cf. S. glanis Linnaeus, 1758. 1, centrum (NMNHU-P 41/2731, Vinogradovka 1). 2, centrum (NMNHU-P 53/4698, Nerubaiske). 3, centrum (NMNHU-P 41/1165, Shkodova Gora). 4, centrum (NMNHU-P 29/3973, Shirokino). 5, centrum (NMNHU-P 37/797, Trudomirovka). 6, centrum (NMNHU-P 45/4052, Cherevichne 2). All centra (Figure 6.1, 6.3-6 - abdominal, Figure 6.2 - caudal) are presented in anterior view. 7, fragment of parasphenoid (NMNHU-P 41/680, Shkodova Gora). Scale bars equal $10 \mathrm{~mm}$.

\section{DISCUSSION}

\section{Taxonomic Composition}

Catfishes in the fossil record of Southeastern Europe are represented by six species, including two extinct (†Heterobranchus austriacus, †Silurus spinosus n. sp.), two extant (Silurus soldatovi, $S$. glanis) and two (Silurus cf. S. glanis, Silurus sp.) that cannot be assigned to any species at this time. All known species are members of two genera (Heterobranchus, Silurus) and two families - Clariidae and Siluridae.
The presence of $\dagger$ Heterobranchus austriacus in the late Miocene of Southeastern Europe is rather interesting. That species was reported previously from the late Miocene of Central and Western Europe (Thenius, 1952; Böhme, 2002; Böhme and Ilg, 2003), and its presence in Eastern Europe is documented here for the first time. Another extinct member of this genus - †Heterobranchus palaeindicus Lyddeker, 1886 - is known from the Pliocene strata of Ladhyani locality (India) and found there along with other clariids - Clarias batrachus Linnaeus, 1758 and Clarias falconeri Lyddeker, 1886 (Sahni and Khare, 1977). The four 
extant species of Heterobranchus are confined to freshwater bodies of Africa (Ferraris, 2007).

The discovery of numerous remains assigned to Silurus soldatovi in the fossil record of Southeastern Europe is no less interesting. This species (or its morphological analogue - Silurus cf. soldatovi) was reported from the late Miocene and Pliocene of Western Mongolia and Kazakhstan (Sytchevskaya, 1989). The current distribution of this species is restricted to the Far East region: the Amur and Ussuri river basins, as well as Lake Khanka (Froese and Pauly, 2015).

\section{Biogeography}

Diversity of catfishes in the late Miocene, Pliocene and Pleistocene strata of Southeastern Europe sheds light upon the evolutionary history of these fishes and establishing some characteristics of their distribution during the late Cenozoic. Ancient late Miocene ichthyocomplex yielded one primitive silurid species, †Silurus spinosus n. sp., which was reported for the early late Sarmatian of Southern Ukraine. The remains of Heterobranchus austriacus first appeared in the study region somewhat later. That species was found during the whole late Sarmatian (11.0-9.88 Ma) and was likely an African immigrant (Gaudant, 2015), which penetrated to Central and Western Europe around the same time. It is hypothesized that this was not a single expansion (prochoresis) from Africa to Europe and Asia, based the presence of some African native mammals, e.g., rodents (Cricetidae, Muridae, Spalacidae), lagomorphs (Serengetilagus) and ungulates in the fossil record of Southeastern Europe (Topachevsky, 1987; Korotkevich, 1988; Krakhmalnaya, 1996; Topachevsky et al., 1997; Topačevsky and Skorik, 1984). Such migrations were repeated and recurred with a certain periodicity due both to the dynamics of large marine basins in the Eastern Paratethys area as well as with the tectonic activity in the Mediterranean region during the late Miocene and Pliocene.

The first finds of the fossil remains of Silurus soldatovi in the study region are also confined to the late Sarmatian time (Table 1). It is unlikely that this species expanded into Europe from Asia; probably its area in the late Miocene and Pliocene was much more extensive, covering not only the water bodies of Asia, but also Eastern Europe. For a while (until the end of Sarmatian) Silurus soldatovi coexisted with †Heterobranchus austriacus. Later S. soldatovi became the dominant (but hardly the only) form of catfish in the late Miocene and Pliocene freshwater ichthyocomplexes of Eastern
Europe. Evolutionary success of this species may have been the result of the Miocene climatic optimum (Böhme, 2003).

It is difficult to say when extant Silurus glanis appeared for the first time. Undoubted remains of this species are derived from the late Miocene (Shkodova Gora) and middle Pliocene (Kotlovina 1), but some bones from the late (Pontian) stage of the late Miocene and the earliest Pliocene are very similar to those in European catfish and described here as Silurus cf. S. glanis (Table 1). We do not identify these remains as belonging to the same taxon (due to poor preservation), but do not exclude such possibility.

There is no evidence of coexistence of Silurus soldatovi and Silurus glanis in water bodies of Southeastern Europe (Table 1), although it seems quite probable. It appears that Silurus glanis gradually supplanted $S$. soldatovi, with subsequent reduction of the area of the latter species. The loss of Silurus soldatovi in the late Pliocene of Southeastern Europe and success of Silurus glanis from that time through to the present was linked to the changing global climate which underwent a cooling and drying phase as the earth transitioned from greenhouse to icehouse climate (Syabryaj et al., 2007; Ivanov et al., 2011). Increased seasonality with a reduction in the number of cool months meant that temperatures would have favoured species with a wider temperature tolerance and those that spawn in cooler waters. Triantafyllidis et al. (2002) discussed the possible existence of a single (eastern) refugium around the Ponto-Caspian region, from which all populations of Silurus glanis spread throughout Central and Southern Europe. Since this species existed in the study region at least from the middle Pliocene, our data are congruent with that refugial hypothesis.

\section{Evolutionary Trends}

We need to point out some of the morphological changes that occurred within the genus Silurus, in particular related to the pectoral-fin spines. That skeletal element is one of the most numerous for all described catfish taxa in late Miocene, Pliocene and Pleistocene localities (Table 2). In the course of our study certain patterns were noticed; which were manifested in the change of size, shape and orientation of denticulations as well as the number of their rows on the shaft of pectoral-fin spine. At least three stages of such changes can be defined: (1) multiserial denticulations on both medial and lateral margins of pectoral-fin spine shaft (Silurus spinosus n. sp.); (2) stouter uniserial denticulations 
TABLE 2. Anatomical distribution of investigated late Cenozoic catfish remains.

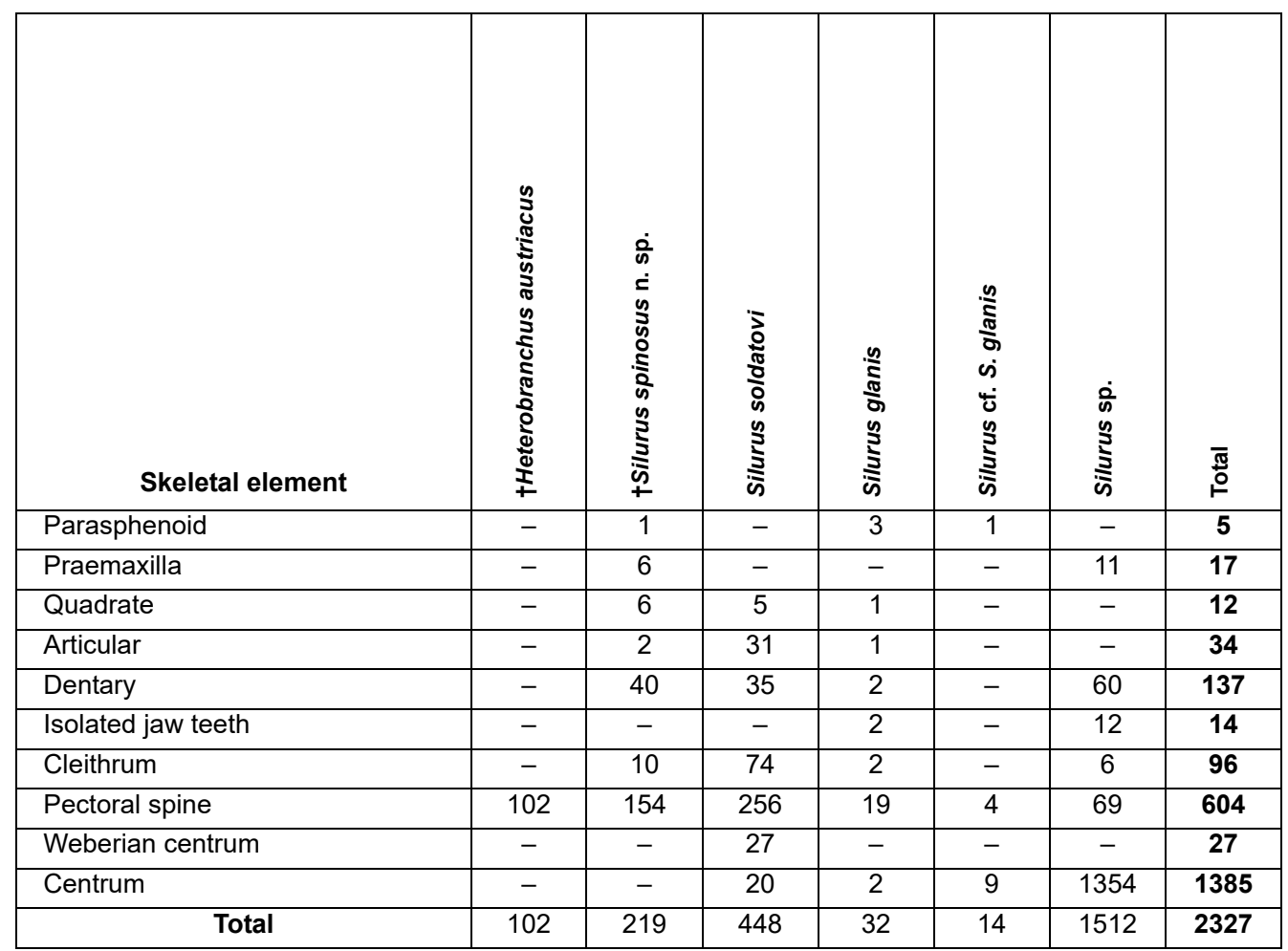

on both margins of the shaft (Silurus soldatovi); (3) very long accrete denticulations only on the medial margin of the pectoral-fin spine shaft (Silurus glanis). We speculate that those changes may be a special case of the oligomerization of homologous structures - the weakening or disappearance some of them, with an increase or appearance of others in the course of a gradual change in their functional load. The reason for this change lies, apparently, in the emergence of innovations in the form of unstable variations (the first appearance of denticulations on pectoral-fin spine), followed by stabilization and consolidation of these acquisitions in descendants (Shishkin, 2012).

\section{ACKNOWLEDGEMENTS}

We extend our gratitude to E.K. Sytchevskaya and S.V. Kurshakov (PIN), L.I. Rekovets (UPW), V.A. Nesin and M.V. Sinitsa (NMNHU-P) for their help and important comments. We are thankful to all curators for allowing access to the comparative osteological collection. Also we are indebted to R. Diogo (HU), R. Fricke (SMNHS), M. Afghah (IAUS) and D. Salinas Torres (UNAM) for their fruitful advice. We further wish to thank executive editor J. Louys, handling editor K. Claeson and the two anonymous reviewers for their positive evaluation of the manuscript.

\section{REFERENCES}

Agassiz, L. 1856. The identity of the Glanis of Aristotle. Proceedings of the American Academy of Arts and Sciences, 3:325-334.

Böhme, M. 2002. Freshwater fishes from the Pannonian of the Vienna Basin with special reference to the locality Sandberg near Götzendorf, Lower Austria. Courier Forschungsinstitut Senckenberg, 237:151173.

Böhme, M. 2003. The Miocene Climatic Optimum: evidence from ectothermic vertebrates of Central Europe. Palaeogeography, Palaeoclimatology, Palaeoecology, 195:389-401.

Böhme, M. and Ilg, A. 2003. Fossil Fishes, Amphibians, Reptiles and Birds (fosFARbase) localities and taxa from the Triassic to the Neogene. www.wahrestaerke.com.

Bonaparte, C.L. 1846. Catalogo Metodico dei Pesci Europei. Stamperia e Cartieri del Fibreno, Napoli.

Cuvier, G. 1816. Le Règne Animal Distribué d'après son Organisation pour Servir de Base à l'Histoire Naturelle des Animaux et d'Introduction à l'Anatomie Comparée. Tome 2. Les Reptiles, les Poissons, les Mollusques et les Annélides. Deterville, Paris.

Diogo, R., Oliveira, C., and Chardon, M. 2001. On the Osteology and Myology of Catfish Pectoral Girdle, 
with a Reflection on Catfish (Teleostei: Siluriformes) Plesiomorphies. Journal of Morphology, 249:100125.

Ferraris, C.J. 2007. Checklist of catfishes, recent and fossil (Osteichthyes: Siluriformes), and catalogue of siluriform primary types. Zootaxa, 1418:1-628.

Froese, R. and Pauly, D. 2015. FishBase. www.fishbase.org.

Gaudant, J. 1994. Die Fischfauna aus dem Ober-Pannonien von Götzendorf an der Leitha, Niederösterreich. Annalen des Naturhistorischen Museums in Wien, 96A:117-131.

Gaudant, J. 2015. Re-examination of the upper Miocene freshwater fish fauna from Höwenegg (Hegau, Germany). Swiss Journal of Palaeontology. doi: 10.1007/ s13358-015-0073-2.

Geoffroy-Saint-Hilaire, E.F. 1809. Poissons du Nil, de la Mer Rouge et de la Mediterranée. In Savigny, J. (Ed.), Description de l'Egypte. Histoire naturelle, Paris, l:1-52.

Gillet, S., Gramann, F., and Steffens, P. 1978. Neue biostratigraphische Ergebnisse aus dem brackischen Neogen an Dardanellen und Marmara-Meer (Türkei). Newsletters in Stratigraphy, 7:53-64.

Head, M.J., Gibbard, P.L., and van Kolfschoten, Th. 2015. The Quaternary System and its formal subdivision. Quaternary International, 383:1-3.

Ivanov, D., Utescher, T., Mosbrugger, V., Syabryaj, S., Djordjecić-Milutinović, D., and Molchanoff, S. 2011. Miocene vegetation and climate dynamics in Eastern and Central Paratethys (Southeastern Europe). Palaeogeography, Palaeoclimatology, Palaeoecology, 304:262-275.

Kamenov, B. and Kojumdshieva, E. 1983. Stratigraphy of the Neogene in the Sofia Basin. Palaeontology, Stratigraphy and Lithology (Bulgarian Academy of Sciences), 18:69-84.

Kobayakawa, M. 1989. Systematic revision of the catfish genus Silurus, with description of a new species from Thailand and Burma. Japanese Journal of Ichthyology, 36:155-186.

Koken, E. 1891. Neue Untersuchungen am tertiären Fisch-Otolithen, II. Zeitschrift der Deutschen Geologischen Gesellschaft, 43:77-170.

Korotkevich, E.L. 1988. History of forming of the Hipparion fauna of Eastern Europe. Naukova dumka, Kiev. (In Russian)

Kovalchuk, O.M. [A.N.] 2011. Freshwater fish community in the lake deposits of the Late Miocene locality Egorovka (Odessa region). Zbirnik prats Zoologichnogo muzeyu, 42:128-136. (In Russian)

Kovalchuk, O.M. 2015. Fishes from excavations of the settlement of XIII-XII centuries BC near Vinohradnyi Sad village (Mykolaiv region, Ukraine). Studia Biologica, 9:201-210. (In Ukrainian)

Kovalchuk, O.M., Zakharov, D.S., Marareskul, V.A., and Obadă, T.F. 2014. Early Pliocene fishes from Priozernoe locality (Republic of Moldova). Acta Zoologica Cracoviensia, 57:43-55.
Kovalchuk, O.M., Marareskul, V.A., Zakharov, D.S., and Obadă, T.F. 2015. Early Pliocene sturgeons and bony fishes from the Dniester valley (Republic of Moldova). Vestnik Zoologii, 49:49-56.

Krakhmalnaya, T.V. 1996. Ancient Maeotian hipparion fauna of the North Black Sea region. Naukova dumka, Kiev. (In Russian)

Krochmal, A.I. and Rekovets, L.I. 2010. Localities of small mammals from the Pleistocene of Ukraine and adjacent territories. LAT \& K, Kyiv. (In Russian)

Lepiksaar, J. 1994. Introduction to Osteology of Fishes for Paleozoologists. Göteborg.

Linnaeus, C. 1758. Systema naturae per regna tria naturae, secundum classes, ordines, genera, species, cum characteribus, differentiis, synonymis, locis. T. I (10 $0^{\text {th }}$ Ed.). Laurentii Salvii, Holmiae (Stockholm), Sweden.

Lundberg, J.G. 1975. The Fossil Catfishes of North America. Claude W. Hibbard Memorial Volume II. Papers on Paleontology, 11:1-51.

Lyddeker, R. 1886. The Indian Tertiary and Post-Tertiary Vertebrata. Tertiary fishes. Palaeontologia Indica, 10:1-264.

Mori, T. 1936. Descriptions of one new genus and three new species of Siluroidea from Chosen. Dobutsugaku Zasshi, 48:671-675. (In Japanese and English)

Nelson, J.S. 2006. Fishes of the World. John Wiley and Sons Inc., New York.

Nesin, V.A. 2013. Neogene Murinae (Rodentia, Muridae) of Ukraine. Universytets'ka knyga, Sumy. (In Russian)

Nesin, V.A. and Nadachowski, A. 2001. Late Miocene and Pliocene small mammal faunas (Insectivora, Lagomorpha, Rodentia) of Southeastern Europe. Acta Zoologica Cracoviensia, 44:107-135.

Nikolsky, G.V. and Soin, S.G. 1948. On the catfish (family Siluridae) of Amur Basin. Proceedings of the Academy of Sciences of USSR, 59:1357-1360. (In Russian)

Otero, O. and Gayet, M. 2001. Palaeoichthyofaunas from the Lower Oligocene and Miocene of the Arabian Plate: palaeoecological and palaeobiogeographical implications. Palaeogeography, Palaeoclimatology, Palaeoecology, 165:141-169.

Regan, C.T. 1907. Descriptions of three new fishes from Yunnan, collected by Mr. J. Graham. Annals and Magazine of Natural History (Ser. 7), 19:63-64.

Rückert-Ülkümen, N., Böhme, M., Reichenbacher, B., Heissig, K. Witt, W., and Bassler, B. 2002. Die Fossilführung des kontinentalen Neogens (Ober-Miozän/ Unter-Pliozän) von Develiköy (Manisa, Turkey). Mitteilungen Bayerische Staatsammlung Paläontologie historische Geologie, 42:51-74.

Rückert-Ülkümen, N. and Yigitbaş, E. 2006. Pharyngeal Teeth, Lateral Ethmoids, and Jaw Teeth of Fishes and Additional Fossils From the Late Miocene (Late Khersonian/Early Maeotian) of Eastern Paratethys 
(Yalova, Near Istanbul, Turkey). Turkish Journal of Earth Sciences, 16:211-224.

Sahni, A. and Khare, S.K. 1977. A Middle Siwalik fish fauna from Ladhyani (Haritalyangar), Himackal Pradesh. Biological Memoirs, 2:187-121.

Schwarzhans, W. 2003. Fish otoliths from the Paleocene of Denmark. Geological Survey of Denmark and Greenland Bulletin, 2:1-94.

Schwarzhans, W. 2010. Otolithen aus den Gerhartsreiter Schichten (Oberkreide: Maastricht) des Gerhatrsreiter Grabens (Oberbayern). Palaeo Ichthyologica, 4:1-100.

Shishkin, M.A. 2012. System-defined morphogenesis and its display in the fossil record. Paleontological journal, 4:3-15. (In Russian)

Syabryaj, S., Utescher, T., Molchanoff, S., and Bruch, A.A. 2007. Vegetation and palaeoclimate in the Miocene of Ukraine. Palaeogeography, Palaeoclimatology, Palaeoecology 253:153-168.

Sytchevskaya, E.K. 1980. Family Siluridae, p. 61-62. In Novitskaya, L.I. (ed.), Fossil Teleost Fishes of the USSR. Nauka, Moscow. (In Russian)

Sytchevskaya, E.K. 1989. Freshwater Neogene Ichthyofauna of Mongolia. Trudy Sovmestnoy SovetskoMongolskoy Paleontologicheskoy Ekspeditsii. No. 39. Nauka, Moscow. (In Russian)

Tarashchuk, V.I. 1962. Materials on the study of freshwater fishes from the Neogene and Anthropogene sediments of Ukraine. Zbirnyk prats Zoologichnogo muzeyu AN URSR, 31:3-27. (In Ukrainian)

Tarashchuk, V.I. 1965. Ectothermic vertebrates from the Pliocene sediments of Zaporozhye region, pp. 74101. In Pidoplichko, I.G. (ed.), Prirodnaya obstanovka $i$ fauny proshlogo. Is. 2. Naukova Dumka, Kiev. (In Russian)

Thenius, E. 1952. Welsreste aus dem Unterpliozän des Wiener Beckens. Neues Jahrbuch für Geologie und Paläontologie, Monatshefte, 1952:80-94.

Tomoda, Y. 1961. Two new catfishes of the genus Parasilurus found in Lake Biwa-ko. Memoirs of the College of Science, Kyoto University (Ser. B), 28:347-354.
Topachevsky, I.V. 1987. The First Find of the Genus Serengetilagus Representative (Lagomorpha, Leporidae) from Pliocene deposits of the Eastern Europe. Vestnik Zoologii, 6:48-51. (In Russian)

Topachevsky, V.A., Nesin, V.A., and Topachevsky, I.V. 1997. An Essay of the Small Mammal Fauna History (Insectivora, Lagomorpha, Rodentia) in Ukraine During Middle Sarmat-Aktchagyl Period. Vestnik Zoologii, 31:3-14. (In Russian)

Topachevsky, V.A., Nesin, V.A., and Topachevsky, I.V. 1998. Biozonal Microtheriological Scheme (Stratigraphic Distribution of Small Mammals - Insectivora, Lagomorpha, Rodentia) of the Neogene of the Northern Part of the East Parathetis. Vestnik Zoologii, 32:76-87. (In Russian)

Topačevsky, V.A. and Skorik, A.F. 1984. The First Find of a Lophiomyinae (Rodentia, Cricetidae) Fossil Representative. Vestnik Zoologii, 2:57-60. (In Russian)

Triantafyllidis, A., Krieg, F., Cottin, C., Abatzopoulos, T.J., Triantaphyllidis, C., and Guyomard, R. 2002. Genetic structure and phylogeography of European catfish (Silurus glanis) populations. Molecular Ecology, 11:1039-1055.

Valenciennes, A. 1839. Poissons; Catalogue des principales espèces de poissons, rapportées de l'Amérique méridionale. In d'Orbigny, A. (ed.), Voyage dans L'Amérique Méridionale (le Brésil, la République Orientale de l'Uruguay, la République Argentine, la Patagonie, la République du Chili, la République de Bolivia, la République du Pérou), Exécuté Pendant les Années 1826, 1827, 1828, 1829, 1830, 1832 et 1833. Vol. 5 (pt. 2), Bertrand et Levrault, Paris.

Weiler, W. 1928. Pisces, p. 48-53. In Stromer, E. (ed.), Wirbeltiere im Obermiozänen Flinz Münchens. Abhandlungen der Bayerischen Akademie der Wissenschaften, Mathematisch-Physikalische Klasse, 32.

Weinfurter, E., 1954. Pisces, p. 30-41. In Papp, A. and Thenius, E. (eds.), Ein Lebensbild aus dem Pannon des Wiener Beckens. Mitteilungen der Geologischen Gesellschaft Wien, 46. 


\section{APPENDIX}

Comparative material examined. All specimens are dried skeletons and c\&s (cleared and stained) bones. Each number represents an individual specimen.

Silurus glanis: NMNHU-P 1/113, 114, 115, 117, 118, 119, 120, 121, 122, 123, 124, 125, 216, 218 (dried skeletons); NMNHU-P 1/126 (c\&s).

Silurus soldatovi: PIN (comparative collection) - quadrate, articular, dentary, hyomandibular, epihyal, ceratohyal, cleithrum, pectoral spine, Weberian centrum (c\&s).

Silurus asotus: PIN (comparative collection) - pectoral spine (c\&s).

Additional data for comparison were obtained from literature:

†Heterobranchus austriacus: pectoral spine (see Thenius, 1952; Weinfurter, 1954; Böhme, 2002).

†Parasilurus altus: complete skeleton (see Sytchevskaya, 1989).

†Silurus joergi: complete skeleton, isolated bones (see Gaudant, 2015).

Silurus cf. S. soldatovi: isolated bones (see Sytchevskaya, 1989).

Silurus aristotelis: skull, shoulder girdle, pectoral spine (see Kobayakawa, 1989).

Silurus biwaensis: pectoral spine (see Kobayakawa, 1989); cleithrum, praemaxilla, pectoral spine,
Weberian centrum (see Kobayakawa and Okuyama, 1994).

Silurus cochinchinensis: skull, shoulder girdle, pectoral spine (see Kobayakawa, 1989).

Silurus glanis: pectoral spine (see Kobayakawa, 1989); skull (see Ünlü et al., 2012).

Silurus grahami: skull, pectoral spine (see Kobayakawa, 1989).

Silurus microdorsalis: skull, shoulder girdle, pectoral spine (see Kobayakawa, 1989).

Silurus triostegus: skull, pectoral spine (see Ünlü et al., 2012). 